\title{
DEVELOPMENT OF CORPORATE MARKETING COMMUNICATION (CMC) BRANDING MODEL IN IAIN TULUNGAGUNG: TOWARD THE ERA OF WORLD CLASS UNIVERSITY
}

\author{
Agus Purwowidodo1, Muhamad Yasin' \\ ${ }^{1}$ Islamic Educational Management Department, Institut Agama Islam Negeri Tulungagung, \\ Tulungagung, East Java, Indonesia \\ ${ }^{2}$ Islamic Educational Management Department, Institut Agama Islam Negeri Kediri, \\ Kediri, East Java, Indonesia \\ Email: widodopurwo74@gmail.com¹, muhamadyasin7106@gmail.com²
}

DOI: http://doi.org/10.33650/al-tanzim.v5i1. 1882

\begin{tabular}{l|l|l} 
Received: January 2021 & Accepted: March 2021 & Published: March 2021
\end{tabular}

\begin{abstract}
:
The study describes and analyzes the use of corporate marketing communication strategies towards Higher Education at the international level. This study used a qualitative descriptive method, with the research site at IAIN Tulungagung. The research subjects are members of the academic community, teaching staff, education staff and stakeholders. The research period was for the 2018/2019 academic year. The results showed that the typology of the marketing or promotion model used collaboration between internal parties (academics, stakeholders) and external parties (institutions, channel partners, media, government, industrial bodies and institutions, the educational community and the general public). Its implementation uses corporate advertising, sponsorship, sales presentations, online activities, branding, corporate advertising, press releases, press conferences, events, and awards. The study implications deal with the increase in: (1) Higher Education Identity, Image, Reputation; (2) Higher Education Social Responsibility (CSR); (3) media relation effectiveness; (4) more efficient marketing communications; (5) the more intensive Internal Communication System; (6) investor relation improvement; (7) conducive relations with the Government, and (8) the reliability in overcoming crisis communication. These have an impact on improving the quality of IAIN Tulungagung toward the level of International Higher Education.
\end{abstract}

Keywords: Branding, Communication, Marketing, University

Abstrak:

Penelitian mendeskrifsikan dan menganalisis pemanfatan strategi corporate marketing communication menuju Peguruan Tinggi pada level Internasional. Penelitian ini menggunakan metode deskriftif kualitatif, dengan situs penelitian di IAIN Tulungagung. Subjek penelitian anggota civitas akademika tenaga pendidik dan tenaga kependidikan serta stakeholder. Periode penelitian tahun ajaran 2018/2019. Hasil Penelitian menunjukkan typology model corporate marketing communication pemasaran menggunakan model kolaborasi dan integrasi pihak internal (civitas akademika, stakeholder) dan eksternal (lembaga, mitra saluran, media, pemerintah, badan industri dan lembaga, masyarakat pendidikan dan umum). Implementasinya dengan memanfaatkan iklan korporat, sponsor, presentasi sales, aktivitas online, branding, iklan korporat, press release, press conference, acara, 
penghargaan. Implikasinya (semakin meningkatnya: (1) Identitas, Citra, Reputasi Perguruan Tinggi; (2) Tanggung Jawab Sosial (CSR) Perguruan Tinggi meningkat ; (3) Hubungan Media semakin efektif; (4) Komunikasi Pemasaran semakin efisien; (5). Sistem Komunikasi Internal semakin intensif; (6) Hubungan investor semakin meningkat; (7) Hubungan dengan Pemerintah semakin kondusif, serta (8) kehandalan dalam mengatasi Komunikasi Krisis. Hal ini berdampak pada peningkatan kualitas IAIN Tulungagung menuju level Perguruan Tinggi Internasional.

Kata Kunci: Branding, Komunikasi, Pemasaran, Universitas

\section{INTRODUCTION}

There is a process of globalization that every person seems to be required to master the knowledge and abilities that can be used as the main capital to enter the free market economy. The aim is to be able to compete and win the global competition. The impact of globalization makes developing countries (new emerging and developing countries) feel that they must equalize their quality in line with developed countries seen from the Human Development Index (HDI), the Program for International Student Assessment (PISA), and others. The business toward world-class university has become a necessity to survive and compete amid globalization. Since then various universities in Indonesia are competing to become international universities. World Class University (WCU) seems to have become a guideline for the parameters of universities in Indonesia to improve quality to be able to compete with foreign universities (Mittelman, 2017).

One of the efforts to bridge these hopes and ideals is by increasing the marketing of Islamic education institutions. The stigma of educational services and marketing activities that were previously considered taboo as they are synonymous with business and tend to be profit-oriented has now undergone a shift. In other words, the reality of education services has an important role in the development and improvement of the quality of human resources. Marketing is one of the means to drive the progress of educational institutions. The challenges of the global era are increasingly complex and must be responded to by the presence of high-quality educational institutions.

According to Reid et al., (2005) in the case of universities, an appropriate strategy is needed to be able to promote higher education. Promoting a college is not only talking about marketing questions but also related to the internal and external factors that influence it, which involves service, behavior, organization, culture, government, corporate identity, corporate image, and so forth, and this is where the public relations task is (Crane, 2016). Public relations and marketing are two things that are philosophically different (Saputri, 2020). Public relations aims to build an image (to the public target) while marketing to sell products (product selling) to the target market. Starting from these two different things, a concept of Marketing Public Relations (MPR) emerged. Public Relations Marketing (MPR) is a combination of Public Relations and Marketing (Sondoh et al., 2007).

This concept is first introduced by Barnes (2013) about Marketing and branding which are two things interconnected with each other. Marketing talks about a product idea, distribution systems and sales chains, the size of gross 
margins, budget promotions, and some of the possible profits to be achieved by producers (Permana, 2012). Branding has the purpose of forming perceptions that are correct in the eyes of consumers so that consumers can understand what is offered by a brand.

The function of branding is to help marketing in terms of product appearance, adjusting product design with the positioning to be formed (Aguinis, 2012). Branding talks about a collection of communication activities carried out by universities in the context of the process of building and enlarging the brand. Similarly, IAIN Tulungagung in terms of recruiting new students, several activities are carried out ahead of the admission period for new students. It aims to build a network and a positive image of the institution. The development of the IAIN Tulungagung branding model has survived to this day because of the need for a differentiation whose form may change, yet in terms of function, it still remains. As one of the State Universities, IAIN Tulungagung desperately needs a differentiation considering the level of competition in PTKIN, which is adequately strict. The existing data shows that PTKIN in Indonesia consists of 11 State Islamic Universities (UIN), 25 State Islamic Institutes (IAIN), and 19 State Islamic Colleges (STAIN). IAIN Tulungagung was established as an answer to the needs of the community for higher education in the Kediri Residency which consists of the regions of Tulungagung, Blitar, Trenggalek, and Kediri.

Education is believed to be a strategic tool for building civilization and improving human life. Through education, humans become intelligent, have abilities or skills, good attitude to life, from which they get along well in society. Education is an investment that provides social and personal benefits that make the nation dignified and the individual becomes a person who has dignity (Bhattacharya, 2004).

The reality of the IAIN Tulungagung has basic tasks and functions that are not light. Therefore, in the operationalization of office tasks, a managerial system is needed to attain quality in all aspects. Educational institutions can become one form of service that truly has a circular process in the era of globalization even after the enactment of the ASEAN Economic Community (MEA).

Universities must have good branding and maintain it to exist in the face of competition at an inter-university that is increasingly tight in the Era of the Asean Economic Community. The MEA (ASEAN Economic Community) is a competitive process or the integration of economic fields in the ASEAN member countries. The establishment of an MEA agreement to realize the ASEAN 2020 insight aims to empower ASEAN member countries to be more active, productive, and develop more rapidly in the world. In the MEA agreement, each member facez a free market and trade zone in the Southeast Asia region (Chen, 2009). This means that trade is no longer limited by territory, such as in Indonesia, but can be carried out to various countries in the Southeast Asia region. Therefore, the existence of the MEA has an impact on the pace of PTKIN's development as one of the educational institutions characterized by Islamic values. 
IAIN Tulungagung as one of PTKIN inevitably has good branding and strive to exist in the face of increasingly fierce college competition towards the World Class University era. Because a college that does not have good branding will be easily forgotten by stakeholders. On the other hand, we can also deny the incessant promotion efforts carried out by foreign universities to attract new student candidates in Indonesia. Thus, the effort to maintain and improve the quality of branding at IAIN Tulungagung is a must, and this is formulated within the research questions below how are the typology, implementation, implications of developing IAIN Tulungagung corporate marketing communication (CMC) branding model toward the Era of World Class University?.

\section{RESEARCH METHODS}

This research was conducted in the light of a descriptive qualitative approach, which describes the existing phenomena (Sukmadinata, 2011), both natural phenomena and human engineering from the participant's perspective. Data were collected through observation, interview, and documentation including literature examinations. The data analysis was staged throughout the field, in which the analysis was carried out as the process of data collection took place or after the completion of data collection in a certain period. Data analysis covered all data obtained through observation, in-depth interviews and documentation, with three stages including data display, data reduction, drawing conclusions and verification. IAIN Tulungagung is a public Islamic university located in Tulungagung, Indonesia. This Islamic college was founded on August 6, 2013 in accordance with Presidential Decree Number 50 of 2013. The university consists of 4 Faculties, namely Sharia and Law (FASIH), Education and Teacher Training (FTIK), Ushuluddin, Adab and Da'wah (FUAD), Islamic Economics and Business (FEBI). There are also several magister programs including 12 study programs and the Doctorate program consisting of 2 study programs. The subjects of this study were all academicians of IAIN Tulungagung and stakeholders. The research period is the second semester of the 2018/2019 academic year.

\section{RESULTS AND DISCUSSION \\ Development Model of Branding Corporate Marketing Communication (CMC)}

Branding development is one of the efforts of IAIN Tulungagung in building an image based on reputation and achievement. This image is a public response to the IAIN Tulungagung positively and negatively that is closely related to respect, good impressions and trust in the IAIN institution as a credible, and qualified educational institution. The Branding Model with CMC at IAIN Tulungagung has been able to form an accumulation of broad public opinion that is impressed by IAIN Tulungagung institution, related to the quality of its outcomes (qualified and competitive graduates), and able to face prejudice risks to misunderstanding. 
The image of the IAIN Tulungagung toward the realization of a worldclass university-level university is carried out by IAIN Tulungagung public relations management and its outcome using good awareness, and is accepted with good perception (take and give) by the community or stakeholders by showing sourness. Introduction to the identity of IAIN Tulungagung, logo attributes brand name, uniform, pre front liner, infrastructure and superstructure of the building, and the appearance of professionals (lecturers and employees) raise the image of IAIN Tulungagung as a figure of a positive image of an education institution, which is better known and accepted by the public or stakeholders from the aspects of history, quality, success in the field of marketing, and social responsibility.

The promotion model based on the CMC branding model at IAIN Tulungagung was carried out so that consumers (communities or stakeholders) knew that the company (IAIN Tulungagung) launched a new product (department or study program) and allowed consumers (community or stakeholders) to make purchases (lecture at IAIN Tulungagung) through the precision of strategy, smart, and appropriate innovation in the promotion.

Promotional strategies which are developed at IAIN Tulungagung use promotional mixes with 5 (five) channels, namely: (1) advertising; (2) personal sales; (3) sales promotion; (4) publishes; and (5) and public relations.

Advertising, as an effective strategy for IAIN Tulungagung to reach prospective students and parents who are geographically dispersed, is done through radio, television, mass media, and internet. Advertising is used to build a long-term image for the outcome (alumnus) and accelerates the number of new students. Personal sales, one of the marketing strategies in the form of direct communication with prospective new students and parents to do the prospect of entering IAIN Tulungagung is done by holding activities in the form of educational exhibitions (Edu-fair), camps, and various sports competitions on campus, competitions, seminars, and workshops, as well as tryouts for senior high school / Islamic senior high school (MA) students. Sales promotion, as a short-term strategy of IAIN Tulungagung to create stronger and faster responses to prospective students and parents is done through scholarship offers, zero UKT (single tuition) for the Al-Qur'an memorizing students, orphans, and the native from Plosokandang.

Publicity is direct marketing carried out by IAIN Tulungagung in the form of letters, telephone, e-mail, websites to communicate with prospective new students and their parents to get a direct response. The role of Public Relations at IAIN Tulungagung is to create a public understanding of the existence of institutions to create a good image, if the promotion aims to communicate the existence of the product (alumni or graduates), public relations communicates with the entire institution. This is done through networking between PTKIN/ PTKIS inside and outside the country, government, educational institutions (SMA/ MA), mass organizations (NU, Muhammdiyah, Persis), which aims to create a better public opinion or image so that it deepens the trust of the IAIN Tulungagung institution. 
Based on observations of researchers, the stages of the branding process of corporate marketing communication (CMC) at IAIN Tulungagung are conducted as the following: (1) Stage of data collection and real condition of the community or stakeholders, which is based on orientation and information on the evaluation activities of the previous year's promotional and marketing activities. This stage is to determine which activities need to be improved and which ones should be continued. Formal initial research is conducted on prospective new students. Informal research is also conducted by conducting interviews with career guidance teachers, students, new students, and journalists. Besides, a group discussion forum was held with the marketing and promotion teams from each study program at the Faculty; (2) Planning a marketing program by Public Relations IAIN Tulungagung, which is based on the results of collecting data in the community or stakeholders and evaluating marketing activities. In this regard, the Public Relations division of IAIN Tulungagung and its staff plan and budget the marketing program; (3) Consultation with Deputy Chancellors I and II; the Public Relations Division of IAIN Tulungagung is under the Vice Chancellor for Administration and Finance, while marketing and promotion planning under the Vice Chancellor for Academic Affairs; (4) Ratification of Promotional Programs and Budgets and Marketing at the institutional level by the AUAK Chancellor and Kabiro to evaluate all promotional activities of the IAIN Tulungagung; (5) Implementation of marketing programs with the CMC model branding in IAIN Tulungagung is coordinated with community conditions or stakeholders, for example a roadshow activity (presentation to high school / MA) in September and October 2017, which is in accordance with the MOU with SMA / MA. For an advertisement in electronic and virtual print media, it is carried out with supervision from the Deputy Chancellor in the academic field as the person in charge of receiving new students (PMB); (6) Evaluating marketing and promotion programs are conducted by the IAIN Tulungagung Public Relations division at the end of the fiscal year based on evaluation of activities, results, and benefits. This marketing relations management process model is based on Heath's theory (2006), which consists of four stages, namely: (1) analysis; (2) planning; (3) implementation; (4) evaluation.

In the context of this study, the planning process developed by IAIN Tulungagung is the effort of IAIN Tulungagung to build relationships with the community or stakeholders to create positive relationships using reciprocal two-way communication. This relationship-building activity is the focus of public relations activities through the representation of patterns of transaction interactions between the IAIN Tulungagung organization and the community or stakeholders. Relationship management theory explains that communication has a strategic role in building relationships, and the program is evaluated based on its impact on the relationship between organizations in IAIN Tulungagung with the community or stakeholders. As Krisyaontoro states: "Communication is the basis or foundation for making planning stages between the two parties and the public as an initiation tool to develop and maintain relations with the public (Etter, 2013). This opinion illustrates that the relation 
process between the IAIN Tulungagung Public Relations division and the community or stakeholders is an exchange of perceptions, attributes, and different conditions and between them, which enables mutual influence (Cho et al., 2017). The existence of intense communication between the IAIN Tulungagung Public Relations division with outside parties, namely SMA / MA, can create long-term relationships and loyalty to the institution. Management as such has been built based on emotional closeness and on the needs and desires of both parties. Thus, a "take and give" marketing atmosphere in the IAIN Tulungagung strives to reach consensus and collaboration. The role of co-creator of the IAIN Tulungagung Public Relations division succeeds in planning and implementing the program based on the vision and mission of the IAIN Tulungagung.

Corporate communication is the way organizations communicate with various groups of people. Corporate communication is a way to build communication within organizations. Incorporate communication connects the application of communication theory that makes the relationship between corporate communication and the overall university corporate strategy (Cho et al., 2017). Van Riel suggests that corporate communication is the way to communicate which is used by organizations, except for marketing communication. In this respect, Van Riel differs corporate communication from marketing communication.

Corporate communication includes marketing communication and communication management. "Corporate communication" means that the university approaches the coherence for the development of communication within organizations. Communication specialists can adapt to streamline their communication activities by working from a coordinated central strategic framework. Corporate communication adopts the word with a corporate perspective. Derived from the Latin corpus which means "body" or "whole", the word makes communication specialists focus, first and foremost, on the overall problem of the organization. Corporate communication shows the fulfilment of organizational goals. Developing a perspective of high school communication does not require building new functions within the organization.

Grunig and Hunt (2018) in his book, Four Models of Public relations, regard corporate communication as "asymmetric or symmetrical two-way communication to persuade audiences (for example to change attitudes, purchase goods or services, live healthily, etc.) or to form relationships". From the description above, it can be concluded that corporate communication is a forum for sending messages carried out by universities to their audiences. With several audiences, universities can choose to publish themselves to which constituents they are intended to. To get and build the image, the intended audience is public outside of the college. However, to build a strong identity in a college, the intended audience is the ones in the college, and for this, we need a good internal communication system in the process of delivering messages, so that the goals of higher education can be achieved. 
The Corporate Communication Strategy or Activity, which is developed by universities according to Ruslan, as quoted from the crisis public relations book strategy or corporate communication activity, is better known as the public relations mix, as follows: (a) publication; (b) event; (c) news that is created; (d) community involvement; (e) inform or image (telling or reaching for an image); (f) lobbying and negotiation; (g) Social responsibility (Du et al., 2010).

Brand talks about logo or visual identity, shape, color and size. Branding relates to a collection of communication activities carried out by the company in the context of the process of building and enlarging the brand. According to Amalie E. Maulana (Einwiller et al., 2017), Branding is a key element to the marketing strategy of IAIN Tulungagung. With a strong brand, it will help to build the identity of IAIN Tulungagung in the community, and hence can develop a solid stakeholder (Elving, W., 2015).

IAIN Tulungagung in conducting an activity is based on the vision of the PTKI brand in this country. Positioning, according to Daraio et al., (2015) is a branding activity in which it has a special place in the minds of customers or society and hope to be top of mind when people need something that concerns the field of the brand. Positioning is something that must continue to be communicated through various activities that are appropriate and consistent with positioning. This will help a brand in the minds of the community. Judging from the vision and mission of IAIN Tulungagung, positioning as PTKIN that is heading for world class university without leaving local wisdom and based on research and rural resources is quite clear.

\section{Implementation of Branding Development for Corporate Marketing Communication (CMC)}

Implementation of marketing programs in accordance with a predetermined schedule is in the form of: (1) Implementation of marketing programs by obtaining assistance from students, faculty and alumni. The IAIN Tulungagung Public Relations Division coordinates and cooperates with SMA/ MA to determine the time of the roadshow and presentation activities, do networking with printed, electronic and digital mass media to carry out publication activities or publicity; (2) every activity or event marketing program evaluation is carried out. For evaluation on social media, the Public Relations Office of IAIN Tulunggagung uses google analytics to evaluate and measure the IAIN Tulungagung website to the extent that the publications and promotions of IAIN Tulungagung Public Relations division received responses from the public or stakeholders; (3) enhance cooperation with Islamic boarding schools, high schools / MA, PTKIN / PTKIS and stakeholders at home and abroad. The IAIN Tulungagung is also in collaboration with Islamic boarding schools around the Kediri Residency in the activities of madrasa diniyah (Madin); (4) strengthening Islamic academic culture within clear rules for lecturers, employees and students in order to form the corporate identity of IAIN Tulungagung; (5) involving graduates or alumni in the marketing process. Alumnus are involved in marketing activities because they have emotional, cultural closeness when coming from the same area; (7) increasing scholarships 
for outstanding students. This form of approach is used as an effort to attract outstanding students that are unable to study at IAIN Tulungagung. Scholarships are also given to students whose hafidz al-Qur'an starts from 10, 20, 30 juz; (8) conducting synergy between the IAIN Tulungagung Public Relations division with the faculty. In the process of marketing and promotion planning at IAIN Tulungagung, there are stages of the SP4 meeting (Annual Budget Plan) by the Deans and Section Heads (Kabag) of the faculty. This meeting is conducted to harmonize the work program of the Public Relations and faculty division so as to be more effective; (9) there is an increase in the quality and academic quality of lecturers and students as well as the quality of services for the community or stakeholders internally and externally as part of promotion for the community or stakeholders.

From the data presentation above, IAIN Tulungagung Public Relations division develops corporate marketing communication (CMC) branding in accordance with the theories from Habermas (1987), which consist of: (1) identification of the audience or target; (2) determining communication objectives; (3) designing messages; (4) choosing and determining communication channels; (5) determining the amount of the marketing communication budget; (6) determining the promotion mix; (7) measuring the results of promotions; and (8) managing and synergizing supply communication in an integrated manner. From this step, it describes a good and effective process starting from the aspect of planning, implementation to evaluation of marketing activities. The steps of implementing modern marketing are not only developing good products (graduates), but also offering at attractive prices (guaranteed quality of graduates) and making them more affordable (competitive and comparative costs) by the community. IAIN Tulungagung has built communication with the community or potential stakeholders both as communicators and promoters by considering what aspects are communicated, to whom and how often they are promoted to the community or stakeholders. The form of marketing implementation with the mix is in accordance with the theory of Kotler and Keller, which presents mix promotions in the form of: (1) advertising; (2) sales promotion; (3) event and experiences; (4) public relations and publicity; (5) direct marketing; (6) personal selling (Gulenko, 2018). The wide choice of message communication tools and diverse audiences (prospective students and parents) requires IAIN Tulungagung to do integrated marketing communication. Integration of marketing as a process of communication that is designed in an integrated manner covers the implementation strategy in the form of marketing to create customer relationships.

\section{Implications of Corporate Marketing Communication (CMC)}

In the modern era, there are many considerations of the community or stakeholders before making a decision to enter or register as a new student in a college, some of which are the image or brand, cost, and promotion. A good and strong college branding will make the college have a better chance of being chosen by prospective new students. Likewise, with the tuition fees provided 
by higher education institutions, the higher education institution will have the opportunity to be chosen by prospective students. Effective and efficient promotion by universities also has the opportunity to be chosen by prospective new students. The Branding Strategy of Corporate Marketing Communication (CMC) by the Public Relations Division of IAIN Tulungagung is inseparable from the mixed strategy developed, consisting of $4 \mathrm{P}$, namely: Price, promotion, place and product, and additional $3 \mathrm{P}$, namely people, process and technicalevidence. It can be concluded that the $4 \mathrm{P}$ and $3 \mathrm{P}$ have a large impact on influencing community decisions or stakeholders in terms of registering or entering college for new students. The implications of developing corporate marketing communication (CMC) branding in IAIN Tulungagung can be observed from: (1) The image of IAIN Tulungagung that is getting more positive. Promotional performance and customer relations affect the image of IAIN Tulungagung that has advantages in the field of academic services, the quality of teaching staff, representative infrastructure and a conducive academic climate; (2) Increasing number of students. In carrying out the promotion strategy, the IAIN Tulungagung uses promotion mix, namely advertising, personal selling, and publicity as the most influential promotion strategy for increasing the number of IAIN Tulungagung students within the last four years; (3) The perception of the community or stakeholders that is getting better. Reorientation of the marketing communication pattern developed by the Public Relations division of IAIN Tulungagung is able to realize harmonization focused on a good image of the IAIN Tulungagung institution. This public positive perception has an impact on community participation in promoting IAIN Tulungagung to the public; (4) Several educational institutions that establish cooperation. With the changing status of STAIN Tulungagung into IAIN Tulungagung, many other educational institutions wish to cooperate, among others are universities in the Middle East, Europe, Australia and Asia. This is done to improve the quality of IAIN Tulungagung; (5) Government care that is getting better. The increasing number of students in 2016 and 2017 has made IAIN Tulungagung receive funding for the construction of SBSN lecture buildings from the government to meet the needs of lecture rooms. The number of infrastructure facilities such as lecture rooms, computers, and laboratories are also increased.

The university management system, particularly in the millennial era, should consider competition focused on quality (Hutami, 2011). Hence, a college in this era ought to prioritize quality both in terms of marketing education services and developing human resources expected to have advantages. The students who study in a college expect the results of communication and multiple motivations, namely science, degree, skills, experience, beliefs, and noble behavior to be in a balanced sense. Everything is required as preparation to enter the world of work or open employment opportunities by expecting a good life with inner and outer welfare.

Many of the university managers have begun to think about implementing a quality system so that it has more values and increases the attractiveness of new students candidate. This is very reasonable in business 
education competition that is getting tighter today. In this pattern of thought, it means that the perceived scope is University as an "educational service organization". It should be realized that the estuary that is aimed at the implementation of a quality system is stakeholder satisfaction (customer satisfaction).

The criteria offered by Sondoh (2017) can be a guarantee for graduates of a tertiary institution so that their competence is undoubtedly in the arena of the international labor market. This can also be a reference for an institution to improve its status as WCU. Some ranking institutions are known by universities in Indonesia such as Times Higher Education Supplement (THES), Webometrics, and Shanghai Jiao Tong University (SJTU).

The Costs and Benefits of World-Class Universities, 'world-class universities' are 'major ranking universities in the world, which have international standards in excellence' (Agung, 2017). These advantages include, among others, excellence in research recognized by the international academic community through international publications; excellence in highly qualified and best-teaching staff (professors) in their fields; excellence in academic freedom and intellectual enthusiasm; management excellence and governance; adequate facilities for academic work, such as a representative library, state-ofthe-art laboratories; adequate funding to support the teaching and learning process and research; and excellence in international cooperation, both in academic programs and research.

Each course has different indicators. For example, QS World University in 2010 established four main criteria that became references, namely: research quality, teaching quality, graduate employability, and international outlook. The indicators used are (1) Quality of the study (academic per review); (2) Ratio of students to teaching staff (student to faculty ratio); (3) Research results cited (citations per paper); (4) Readiness for graduates to enter the world of work (employer review); (5) Publication of teaching staff (papers per faculty); (6) Student exchange (inbound exchange students); (7) Outbound exchange students; (8) Number of foreign students (international students); (9) Number of lecturers teaching abroad. Contributions of research deal with: (a) Providing a description of development model of PTKIN's Corporate Marketing Communication Branding that is successful for the Muslim community and the international community; (b) Providing research-based knowledge for authority holders and education practitioners in Indonesia about the management of the Corporate Marketing Communication Branding Development model in developing resources and redesigning organizations toward achievement of the success of universities and outstanding students; (c) Providing a Corporate Marketing Communication Branding Development Model in developing PTKIN to conduct more in-depth research and determining direction, developing resources and redesigning the organization toward the successful achievement of PTKIN and outstanding students.

This study uses the type of intrinsic case study research with an interpretive approach. An intrinsic case study chooses a case because of its uniqueness and the researchers want to understand more about it The 
interpretive approach seeks to understand human behavior in terms of both the frame of mind and the actions of the people themselves (Moleong, 2018). Case study research is a study that is used to obtain a full and integrated understanding of the realization of various facts and dimensions of a particular case. The case itself is defined as a special phenomenon that is present in a limited context, even though the boundaries between phenomena and contexts are not entirely clear (Poerwandari, 2017).

The case study research is chosen as the researchers want to understand phenomena specifically and deeply, including individuals, groups, and unique situations related to the phenomenon being examined. In this study, the researchers used the intrinsic type of case study in that the research was conducted based on researchers' interest in a particular case. This research was conducted to fully understand the case without having to link to produce concepts or theories or without efforts to generalize.

\section{CONCLUSION}

The Novelty of the research strategy models developed by the IAIN Tulungagung use a promotional mix through five channels, namely: (1) advertising; (2) personal sales; (3) sales promotion; (4) publicity; and (5) and public relations. To establish the branding of the IAIN Tulungagung institution toward the realization to become the world-class university, IAIN Tulungagung public relations management encourage the institution and its outcome to be accepted by the community or stakeholders. It is done by displaying the identity of IAIN Tulungagung, logo attributes, brand name, uniform, pre-front liner, structure, and superstructure of the building, and the appearance of professionals (lecturers and employees).

Implementation of the branding model with the CMC approach is conducted through the strategies as follows: (1) getting assistance from students, faculty, and alumni; (2) carrying out activities or event marketing program evaluation; (3) increasing cooperation with Islamic boarding schools, high schools / MA, PTKIN / PTKIS and stakeholders at home and abroad; (4) strengthening Islamic academic culture with clear rules for lecturers, employees and students; (5) involving graduates or alumni in the marketing process or marketing; (7) increasing scholarships for outstanding students; (8) conducting synergy between the IAIN Tulungagung Public Relations division with the faculty; (9) increasing the academic quality of lecturers and students as well as the quality of services for the community or stakeholders.

The implications of branding with the CMC model are: (a) The image of IAIN Tulungagung is increasingly positive; (b) Number of students increases; (c) The perception of the public or stakeholders is getting better; (d) Number of educational institutions establish cooperation; and (e) Government care is getting better. 


\section{REFERENCES}

Aguinis, H., \& Glavas, A. (2012). What we Know and Don't Know about Corporate Social Responsibility: A Review and Research Agenda. Journal of Management, 38(4), 932-968.

Bhattacharya, C. B., \& Sen, S. (2004). Doing Better at Doing Good: When, why, and How Consumers Respond to Corporate Social Initiatives. California Management Review, 47(1), 9-24.

Crane, A., \& Glozer, S. (2016). Researching Corporate Social Responsibility Communication: Themes, Opportunities and Challenges. Journal of Management Studies, 53(7), 1223-1252.

Du, S., Bhattacharya, C. B., \& Sen, S. (2010). Maximizing Business Returns to Corporate Social Responsibility (CSR): The Role of CSR Communication. International Journal of Management Reviews, 12(1), 8-19.

Einwiller, S., Viererbl, B., \& Himmelreich, S. (2017). Journalists' Coverage of Online Firestorms in German-Language News Media. Journalism Practice, 11(9), 1178-1197.

Elving, W. J., Golob, U., Podnar, K., Ellerup-Nielsen, A., \& Thomson, C. (2015). The Bad, The Ugly and The Good: New Challenges for CSR Communication. Corporate Communications: An International Journal, 2(2), 118-127.

Etter, M. (2013). Reasons for Low Levels of Interactivity: Non Interactive CSR Communication in Twitter. Public Relations Review, 39(5), 606-608.

Hutami, R. R. F. (2011). Research University sebagai Langkah Awal Menuju World Class University. Jurnal Manajemen Indonesia, 11(3), 162-171.

Permana, V. A. (2012). Pengaruh Kinerja Lingkungan dan Karakteristik Perusahaan terhadap CSR Disclosure: Studi Empiris pada Perusahaan Manufaktur yang terdaftar di BEI. Diponegoro Journal of Accounting, 1(2), $1-12$.

Poerwandari, E. K. (2017). Qualitative Approach to Human Behavior Research. Jakarta: LPSP3 Universitas Indonesia.

Sondoh, S. L., Omar, M. W., Wahid, N. A., Ismail, I., \& Harun, A. (2007). The Effect of Brand Image on Overall Satisfaction and Loyalty Intention in The Context of Color Cosmetic. Asian Academy of Management Journal, 12(1), 83-107.

Saputri, A., Hudayah, S., \& Abidin, Z. (2020). Pengaruh Customer Relationship Management dan Kualitas Layanan terhadap Kepuasan dan Loyalitas Pelanggan Media Advertising di Samarinda. e-Journal Ekonomi Bisnis dan Akuntansi, 7(2), 114-119.

Cho, M., Furey, L. D., \& Mohr, T. (2017). Communicating Corporate Social Responsibility on Social Media: Strategies, Stakeholders, and Public Engagement on Corporate Facebook. Business and Professional Communication Quarterly, 80(1), 52-69.

Habermas, J. (1987). The Theory of Communicative Action: Lifeworldand System: A Critique of Functionalist Reason. Boston: Beacon Press.

Moleong, L. J. (2018). Metodologi Penelitian Kualitatif. Bandung: Remaja Rosdakarya. 
Mittelman, J. H. (2017). Implausible Dream: The World-class University and Repurposing Higher Education. New Jersey: Princeton University Press.

Agung, I., \& Santosa, A. (2017). Dinamika LPTK menuju Perguruan Tinggi Kelas Dunia (World Class University/WCU). Perspektif Ilmu Pendidikan, 31(1), 43-54.

Chen, S. (2009). Corporate Responsibilities in Internet-enabled Social Networks. Journal of Business Ethics, 90(4), 523-536.

Daraio, C., Bonaccorsi, A., \& Simar, L. (2015). Rankings and University Performance: A Conditional Multidimensional Approach. European Journal of Operational Research, 244(3), 918-930.

Heath, R. L., \& Coombs, W. T. (2006). Today's Public Relations: An Introduction. California: Sage.

Reid, M., Luxton, S., \& Mavondo, F. (2005). The Relationship Between Integrated Marketing Communication, Market Orientation, and Brand Orientation. Journal of Advertising, 34(4), 11-23. 